\title{
Sporadic pollen consumption among tropical ants
}

\author{
A. R. Cembrowski, G. Reurink, L. M. Arcila Hernandez, E. \\ Youngerman \& M. E. Frederickson, J. G. Sanders, E. \\ Youngerman
}

\section{Version Post-Print $\backslash$ Accepted Manuscript}

Citation Cembrowski, A.R., Reurink, G., Arcila Hernandez, L.M. et al. Sporadic pollen

(published consumption among tropical ants. Insect. Soc. 62, 379-382 (2015).

version) https://doi.org/10.1007/s00040-015-0402-x

DOI https://doi.org/10.1007/s00040-015-0402-x

\footnotetext{
Publisher 1. Archived content may only be used for academic research. Any content downloaded for text Terms of based experiments should be destroyed when the experiment is complete.

Use 2. Archived content may not be used for purposes that are intended for or directed towards transfer or any other form of commercial exploitation ("Commercial Purposes").

3. Archived content may not be published verbatim in whole or in part, whether or not this is done for Commercial Purposes, either in print or online.

4. This restriction does not apply to reproducing normal quotations with an appropriate citation. In the case of text-mining, individual words, concepts and quotes up to 100 words per matching sentence may be used, whereas longer paragraphs of text and images cannot (without specific permission from Springer Nature).

5. All use must be fully attributed. Attribution must take the form of a link - using the article DOI - to the published article on the journal's website.

6. All use must ensure that the authors' moral right to the integrity of their work is not compromised.

7. Where content in the document is identified as belonging to a third party, it is the obligation of the user to ensure that any use complies with copyright policies of the owner.

8. Any use of Springer Nature content is at your own risk and Springer Nature accepts no liability arising from such use.
}

\section{How to cite TSpace items}

Always cite the published version, so the author(s) will receive recognition through services that track citation counts, e.g. Scopus. If you need to cite the page number of the author manuscript from TSpace because you cannot access the published version, then cite the TSpace version in addition to the published version using the permanent URI (handle) found on the record page.

This article was made openly accessible by $U$ of $T$ Faculty. Please tell us how this access benefits you. Your story matters. 


\section{Sporadic pollen consumption among tropical ants}

2 Cembrowski, A.R. ${ }^{1}$, Reurink, G. ${ }^{1}$, Arcila Hernandez, L.M. ${ }^{1,2}$, Sanders, J.G. ${ }^{3}$, Youngerman,

3 E. ${ }^{1,4,5}$, and Frederickson, M.E. ${ }^{*}$

$4{ }^{1}$ Department of Ecology and Evolutionary Biology, University of Toronto, 25 Harbord Street,

5 Toronto, Ontario M5S 3G5, Canada

$6{ }^{2}$ Current address: Department of Ecology and Evolutionary Biology, Cornell University, Ithaca,

$7 \quad$ NY 14853, USA

$8 \quad{ }^{3}$ Department of Organismic and Evolutionary Biology, Harvard University, Cambridge MA

9 02138, USA

$10{ }^{4}$ New Guinea Binatang Research Center, PO Box 604, Madang, Papua New Guinea

$11{ }^{5}$ Current address: Department of Biology, The University of Utah, Salt Lake City, UT 84112,

12 USA

13

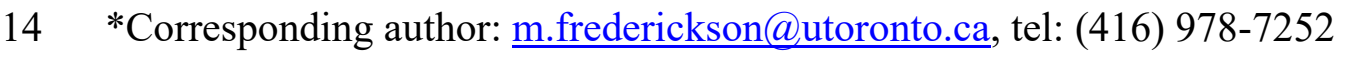

15

16

17

18 


\section{Abstract}

20 Although palynivory, or pollen consumption, is widespread in other Hymenoptera, there are few

21 accounts of palynivory in ants. We subjected adult workers and larvae from 77 species of

22 tropical ants to acetolysis, a process that dissolves most organic material but leaves behind pollen

23 grains. Ants of 38 species contained pollen grains, suggesting that sporadic, opportunistic pollen

24 consumption by ants is common, but not ubiquitous, in tropical forests.

25

\section{Keywords}

27 Acetolysis, ants, palynivory, pollen, tropical forests

28 
29 Palynivory occurs in many taxa, including birds, mammals, and arthropods, but it is best known

30 among the Hymenoptera, particularly bees. Although ants and bees are closely related and have

31 similar nutritional requirements (i.e., adult workers require mostly carbohydrates but forage for

32 protein to feed to larvae), there are only scattered reports of pollen consumption by ants

33 (Creighton 1967; Baroni Urbani and de Andrade 1997; Ness 2006; Czechowski et al. 2009,

34 2011; Byk and Del Claro 2010). We borrowed a technique from palynology, namely acetolysis,

35 to investigate whether palynivory is truly rare among ants or simply under-reported.

36 We collected adult workers and larvae by hand, and adult workers only at baits and from

37 leaf litter using Winkler extractors at the Centro de Investigación y Capacitación Rio Los

38 Amigos (CICRA) in Peru in 2010-2011 and in Madang Province, Papua New Guinea (PNG) in

39 2011-2012. Larvae were always collected from ant nests, but workers were often sampled

40 opportunistically from vegetation or leaf litter. We sorted ants to morphospecies and identified

41 them to genus using taxonomic keys (Shattuck 1999, Palacio and Fernández 2003). We used

42 acetolysis on whole adult workers, dissected adult worker guts (midgut and ileum only,

43 excluding the crop and rectum), and whole larvae to look for pollen grains inside ants. We

44 washed each sample in $70 \%$ ethanol to remove any pollen present on the sample's outer surface

45 before placing it in a micro-centrifuge tube with $\sim 0.5 \mathrm{~mL}$ of a $9: 1$ mixture of acetic anhydride:

46 sulfuric acid. We heated each sample at $95^{\circ} \mathrm{C}$ for $20 \mathrm{~min}$., allowing tissues to dissolve. Next, we

47 centrifuged samples at 1000 RPM for $5 \mathrm{~min}$. and decanted the liquid supernatant, before adding

$48 \sim 0.5 \mathrm{~mL}$ of glacial acetic acid to the precipitate, centrifuging again as above. We decanted the

49 samples and added a drop of distilled water. We examined either all or a $150 \mu \mathrm{L}$ sub-sample of

50 this solution for pollen grains under a light microscope, identifying grains by their staining

51 (pollen appears light to dark brown following acetolysis) and surface architecture. 
In total, we found pollen grains in 30 of the 131 whole adult workers, 7 of the 65

53 dissected adult worker guts, and 21 of the 102 larvae that we examined (Table 1). The number of

54 pollen grains found was often low, but ran as high as 468 grains in one Camponotus worker

55 (Table 1). Pollen presence was inconsistent among conspecific ant samples. Half of the ant

56 species we examined (38 out of 77 ) had at least one individual that had consumed pollen, but

57 multiple individuals contained pollen in only 15 species (Table 1). In only three species (two

58 Cephalotes and one Myrmelachista) did all adult workers contain pollen.

We cannot rule out the possibility that the small numbers of pollen grains we observed

60 resulted from secondary pollen consumption (i.e., consuming a palynivorous organism or liquid

61 containing pollen). However, Cephalotes ants were the only known palynivores among the taxa

62 we sampled (Creighton 1967; Baroni Urbani and de Andrade 1997; Byk and Del Claro 2010),

63 and they contained similar numbers of pollen grains as many of the other ant species that we

64 examined, suggesting that our results represent targeted pollen consumption by ants.

Ants probably eat pollen only sporadically, exploiting other protein-containing foods

more heavily. Although ants regularly visit flowers, the small numbers of pollen grains in most

67 of our samples suggest that ants may collect pollen haphazardly from leaves and other surfaces

68 where pollen lands, and only rarely directly from anthers. Creighton (1967), for example,

69 observed Cephalotes texanus collecting pollen trapped in leaf hairs.

Like Cephalotes, Camponotus consistently contained pollen grains; of the eight species

71 examined, five contained pollen, and pollen was found in Camponotus ants from both Peru and

72 PNG (Fig. 1). Camponotus species also contained the two largest numbers of pollen grains (468

73 and 271). Thus, Camponotus may be another, as yet unrecognized, commonly palynivorous

74 genus. Similarly, some Crematogaster and Odontomachus contained pollen in both Peru and 
75 PNG, while Pheidole never did (Table 1). Overall, our results suggest that intermittent pollen

76 consumption may be relatively common, but not ubiquitous, among tropical ants.

\section{Acknowledgements}

78 We would like to thank CICRA and the New Guinea Binatang Research Center for logistical

79 support. The comments of two anonymous reviewers improved the manuscript. The Peruvian

80 Ministry of Agriculture provided permits. Vouchers specimens are in ant collections at the

81 Harvard Museum of Comparative Zoology (MCZ), the Centro de Ecologia y Biodiversidad

82 (CEBIO) in Lima, Peru, and the Czech Academy of Sciences (CAS). We acknowledge funding

83 from an NSERC Discovery Grant (MEF), an Ontario MEDI Early Researcher Award (MEF), an

84 Ontario Graduate Scholarship (ARC), Sigma Xi (ARC), the Pierce Lab at Harvard (JGS, EY), a

85 Putnam Expedition Grant (JGS), and the Czech Science Foundation (EY, grant number

$86 \mathrm{P} 505 / 10 / 0673)$.

87

88 References

89 Baroni Urbani C, de Andrade ML (1997) Pollen eating, storing, and spitting by ants.

$90 \quad$ Naturwissenschaften $84: 256-258$

91 Byk J, Del-Claro K (2010) Nectar- and pollen-gathering Cephalotes ants provide no protection

92 against herbivory: a new manipulative experiment to test ant protective capabilities. Acta

93 Ethol 13:33-38

94 Creighton WS (1967) Studies on free colonies of Cryptocerus texanus Santschi (Hymenoptera:

$95 \quad$ Formicidae). Psyche 74:34-42 
96 Czechowski W, Markó B, Radchenko A (2008) Rubbish dumps reveal the diet of ant colonies:

97 Myrmica schencki Em. and Myrmica rubra (L.) (Hymenoptera: Formicidae) as facultative $98 \quad$ pollen-eaters. Pol J Ecol 56:737-741

99 Czechowski W, Markó B, Erös K, Csata E (2011) Pollenivory in ants (Hymenoptera:

100 Formicidae) seems to be much more common than it was thought. Ann Zool 61:519-525

101 Ness JH (2006) A mutualism's indirect costs: the most aggressive plant bodyguards also deter 102 pollinators. Oikos 113:506-514

103 Palacio EE, Fernández F (2003) Claves para las subfamilias y géneros. In: Fernández F (ed)

104 Introducción a las Hormigas de la región Neotropical. Instituto de Investigación de

105 Recursos Biológicos Alexander von Humboldt, Bogotá, Colombia, pp 233-360

106 Shattuck SO (1999) Australian Ants: Their Biology and Identification. CSIRO Publishing, 107 Collingwood, Australia 
110 Table 1. Numbers of pollen grains in larvae, dissected guts, and whole worker ants from Peru and Papua New Guinea (PNG). Values for each sample are separated by commas.

\begin{tabular}{|c|c|c|c|c|c|}
\hline Genus & Morphospecies & Region & Larvae & Guts & Whole ants \\
\hline \multicolumn{6}{|c|}{ Aenictinae } \\
\hline Aenictus & sp. 1 & PNG & $1,1,0$ & & $0,0,0$ \\
\hline \multicolumn{6}{|c|}{ Dolichoderinae } \\
\hline Azteca & sp. 1 & Peru & & $0,0,0$ & \\
\hline Azteca & sp. 2 & Peru & & 0,0 & \\
\hline Azteca & sp. 3 & Peru & 0,0 & & \\
\hline Azteca & sp. 4 & Peru & & & 1,0 \\
\hline Azteca & sp. 5 & Peru & & & $2,0,0$ \\
\hline Dolichoderus & decollatus & Peru & & $66,0,0$ & \\
\hline Dolichoderus & sp. 1 & Peru & & $0,0,0$ & \\
\hline Dolichoderus & sp. 2 & Peru & 2 & $0,0,0$ & \\
\hline Dolichoderus & sp. 3 & Peru & $0,0,0$ & $0,0,0$ & \\
\hline Dolichoderus & sp. 4 & Peru & 0,0 & & \\
\hline Philidris & sp. 1 & PNG & 4 & & $0,0,0$ \\
\hline Tapinoma & sp. 1 & PNG & $38,0,0$ & & 0,0 \\
\hline Technomyrmex & sp. 1 & PNG & $12,12,0$ & & \\
\hline \multicolumn{6}{|c|}{ Dorylinae } \\
\hline Labidus & sp. 1 & Peru & & $0,0,0$ & \\
\hline \multicolumn{6}{|c|}{ Ectatomminae } \\
\hline Rhytidoponera & sp. 1 & PNG & $2,0,0$ & & 0 \\
\hline \multicolumn{6}{|c|}{ Formicinae } \\
\hline Acropyga & sp. 1 & PNG & $2,0,0$ & & $0,0,0$ \\
\hline Acropyga & sp. 2 & PNG & $0,0,0$ & & $0,0,0$ \\
\hline Acropyga & sp. 3 & $\mathrm{PNG}$ & $0,0,0$ & & $0,0,0$ \\
\hline Anoplolepis & sp. 1 & PNG & $1,0,0$ & & $1,0,0$ \\
\hline Calomyrmex & sp. 1 & $\mathrm{PNG}$ & $1,0,0$ & & $0,0,0$ \\
\hline Camponotus & sp. 1 & Peru & $0,0,0$ & $0,0,0$ & \\
\hline Camponotus & sp. 2 & Peru & 2 & $82,0,0$ & \\
\hline Camponotus & sp. 3 & Peru & & $3,0,0$ & \\
\hline Camponotus & sp. 4 & Peru & 0,0 & & \\
\hline Camponotus & sp. 5 & Peru & & & $1,1,0,0,0,0,0,0$ \\
\hline Camponotus & sp. 6 & Peru & & & $468,16,7,0$ \\
\hline Camponotus & sp. 7 & Peru & & & $12,0,0,0,0$ \\
\hline Camponotus & sp. 8 & Peru & & & 1,0 \\
\hline Camponotus & sp. 9 & PNG & $0,0,0$ & & $271,1,0$ \\
\hline Camponotus & sp. 10 & PNG & $0,0,0$ & & 0 \\
\hline Camponotus & sp. 11 & $\mathrm{PNG}$ & & & 0,0 \\
\hline Myrmelachista & sp. 1 & Peru & $0,0,0$ & & \\
\hline Myrmelachista & sp. 2 & Peru & & & $18,11,5$ \\
\hline Nylanderia & sp. 1 & PNG & $0,0,0$ & & $0,0,0$ \\
\hline Opisthopsis & sp. 1 & PNG & $0,0,0$ & & $0,0,0$ \\
\hline Paratrechina & sp. 1 & Peru & & & $1,1,0,0$ \\
\hline Polyrhachis & sp. 1 & PNG & $4,0,0$ & & 0 \\
\hline
\end{tabular}




\begin{tabular}{|c|c|c|c|c|c|}
\hline Genus & Morphospecies & Region & Larvae & Guts & Whole ants \\
\hline \multicolumn{6}{|c|}{ Myrmicinae } \\
\hline Atta & sp. 1 & Peru & & $0,0,0$ & \\
\hline Cephalotes & atratus & Peru & & & $21,2,2$ \\
\hline Cephalotes & placidus & Peru & & & $21,4,1$ \\
\hline Cephalotes & sp. 1 & Peru & & $0,0,0$ & \\
\hline Cephalotes & sp. 2 & Peru & & & 0 \\
\hline Cephalotes & sp. 3 & Peru & & & 0,0 \\
\hline Crematogaster & sp. 1 & Peru & & $35,0,0$ & \\
\hline Crematogaster & sp. 2 & Peru & 0 & $0,0,0$ & \\
\hline Crematogaster & sp. 3 & Peru & & & $7,0,0,0,0,0,0,0,0$ \\
\hline Crematogaster & sp. 4 & Peru & & & 0,0 \\
\hline Crematogaster & sp. 5 & PNG & $0,0,0$ & & $0,0,0$ \\
\hline Crematogaster & sp. 5 & $\mathrm{PNG}$ & $0,0,0$ & & $32,0,0$ \\
\hline Megalomyrmex & sp. 1 & Peru & & $0,0,0$ & \\
\hline Megalomyrmex & sp. 2 & Peru & 0,0 & & \\
\hline Megalomyrmex & sp. 3 & Peru & & & $7,0,0,0$ \\
\hline Megalomyrmex & sp. 4 & Peru & & & $0,0,0$ \\
\hline Monomorium & sp. 1 & Peru & $2,0,0$ & & \\
\hline Monomorium & sp. 2 & PNG & $1,0,0$ & & $1,0,0$ \\
\hline Monomorium & sp. 3 & $\mathrm{PNG}$ & $1,1,1$ & & $0,0,0$ \\
\hline Pheidole & sp. 1 & Peru & $0,0,0$ & & \\
\hline Pheidole & sp. 2 & Peru & & $0,0,0$ & \\
\hline Pheidole & sp. 3 & Peru & $0,0,0$ & & \\
\hline Pheidole & sp. 4 & PNG & $0,0,0$ & & $0,0,0$ \\
\hline Pristomyrmex & sp. 1 & $\mathrm{PNG}$ & $1,1,0$ & & $0,0,0$ \\
\hline Procryptocerus & sp. 1 & Peru & & $0,0,0$ & \\
\hline Pyramica & sp. 1 & PNG & & & $0,0,0$ \\
\hline Solenopsis & sp. 1 & Peru & $0,0,0$ & & \\
\hline Solenopsis & sp. 2 & Peru & & & $5,3,0$ \\
\hline Trachymyrmex & sp. 1 & Peru & & & $21,0,0$ \\
\hline Trachymyrmex & sp. 2 & Peru & & & $0,0,0$ \\
\hline Wasmannia & sp. 1 & Peru & & & $0,0,0$ \\
\hline \multicolumn{6}{|c|}{ Ponerinae } \\
\hline Odontomachus & sp. 1 & Peru & & $34,0,0$ & \\
\hline Odontomachus & sp. 2 & PNG & $4,0,0$ & & $0,0,0$ \\
\hline Pachycondyla & sp. 1 & Peru & & $3,0,0$ & \\
\hline \multicolumn{6}{|c|}{ Pseudomyrmecinae } \\
\hline Pseudomyrmex & sp. 1 & Peru & & $0,0,0$ & \\
\hline Pseudomyrmex & sp. 2 & Peru & & $0,0,0$ & \\
\hline Pseudomyrmex & sp. 3 & Peru & & $9,0,0$ & \\
\hline Pseudomyrmex & sp. 4 & Peru & $0,0,0$ & & \\
\hline Pseudomyrmex & sp. 5 & Peru & $0,0,0$ & & \\
\hline
\end{tabular}

